\title{
Studies on Ancient Rice-Where Botanists, Agronomists, Archeologists, Linguists, and Ethnologists Meet
}

\author{
Jaw-shu Hsieh • Yue-ie Caroline Hsing • Tze-fu Hsu • \\ Paul Jen-kuei Li • Kuang-ti Li • Cheng-hwa Tsang
}

Received: 23 October 2011 / Accepted: 5 December 2011 / Published online: 24 December 2011

(C) Springer Science+Business Media, LLC 2011

\begin{abstract}
Taiwan's aboriginal peoples are thought to be related to ancestral Austronesian-speaking peoples. Currently, Taiwan has 14 officially acknowledged aboriginal tribes. The major crops currently farmed in aboriginal areas are rice (Oryza sativa) and foxtail millet (Setaria italica). Archeologists recently excavated the remains of several early cultures in Taiwan. The most plentiful plant remains were carbonated rice and foxtail millet grains. The earliest ${ }^{14} \mathrm{C}$ date of these excavation sites is $\sim 5,000$ B. These settlements may be those of the earliest ancestral Austronesian speakers in Taiwan. Rice domestication is a complex story. In this study, we identified the functional nucleotide polymorphisms of 16 domesticationrelated genes using 60 landraces collected from aboriginal Taiwanese villages about 100 years ago. We also screened the phenotypes of these landraces. By integrating phenoand genotypic data, together with data from archeologists and linguists, we may be able to better understand the history of rice cultivation in Taiwan and nearby areas.
\end{abstract}

Keywords Austronesian · Domestication · Rice · Taiwan

\author{
J.-s. Hsieh \\ Department of Agronomy, National Taiwan University, \\ Taipei, Taiwan \\ Y.-i. C. Hsing $(\bowtie) \cdot$ T.-f. Hsu \\ Institute of Plant and Microbial Biology, Academia Sinica, \\ Taipei, Taiwan \\ e-mail: bohsing@gate.sinica.edu.tw
}

P. J.-k. Li

Institute of Linguistics, Academia Sinica,

Taipei, Taiwan

K.-t. Li $\cdot$ C.-h. Tsang

Institute of History and Philology, Academia Sinica,

Taipei, Taiwan

\section{The aboriginal peoples in Taiwan}

Taiwanese aborigines are the original inhabitants of Taiwan. Recent research suggests that their ancestors may have been living on Taiwan and its surrounding islands for approximately 8,000 years before a major Han Chinese immigration began in the seventeenth century (Blust 1985). Taiwanese aborigines are Austronesian-speaking peoples, with linguistic and genetic ties to other Austronesian ethnic groups such as peoples of the Philippines, Malaysia, Indonesia, Madagascar, Polynesia, and Oceania (Hill et al. 2007).

During the late sixteenth century, Taiwan had two major aboriginal groups or tribes: "Plains," or lowland tribes (in Chinese: Pingpu zu), and "High Mountain" or highland tribes (Gaoshan zu). The former consisted of eight separate tribes: Luilang, Ketagalan, Taokas, Pazeh, Papora, Babuza, Hoanya, and Siraya. Most of these were assimilated into the Han culture about 300 years ago. The latter group consists of 14 tribes (Council of Indigenous People, http://www.apc. gov.tw/). Figure 1 indicates the general location of each of these High Mountain peoples. The following describes their location and population:

1. Atayal: northern part of Taiwan's Central Mountain area; about 81,000 people.

2. Truku: along the Liwu River Valley to the east, about 24,000 people.

3. Sakizaya: Chilai plain of Hualien County, about 335 people.

4. Kavalan: once lived in Yilan but now located in the areas of Hualien and Taitung, about 1,100 people.

5. Amis: the largest group of indigenous people in Taiwan and distributed along the plains surrounding Mount Chilai in northern Hualien County, south through to the long and narrow coastal plains and hilly areas of Taitung 


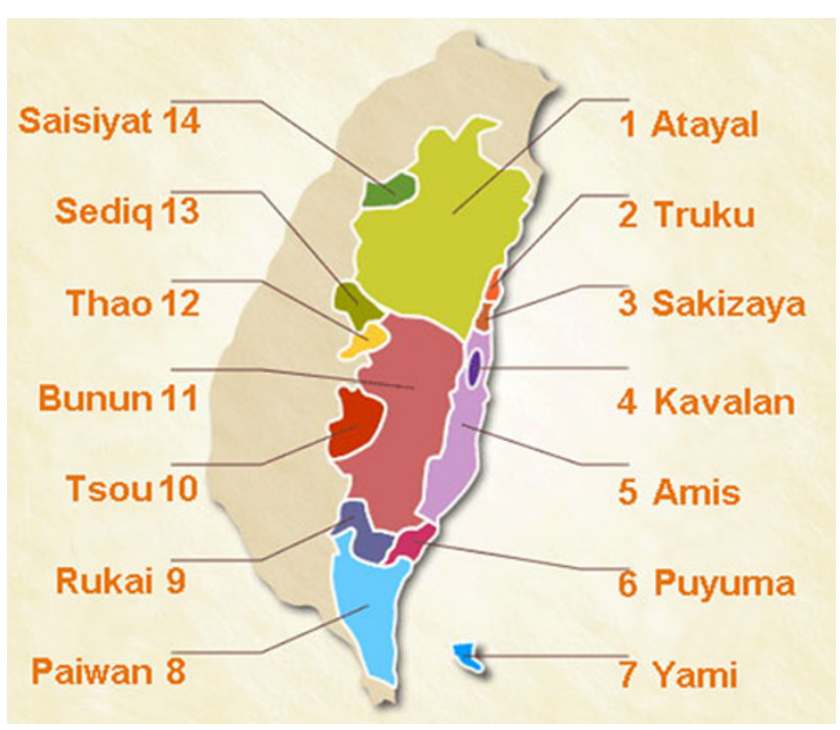

Fig. 1 Distribution of Taiwan's aboriginal peoples (data from the Council of Indigenous Peoples, Taiwan; http://www.apc.gov.tw/).

County and Pingtung's Hengchun Peninsula, about 177,000 people.

6. Puyuma: southern area of the Taitung Longitudinal Valley, about 11,000 people.

7. Yami: Orchid Island, off the coast of Taitung County; the only oceanic tribe in Taiwan, about 3,500 people spread over six island villages. Because of their isolated location, their culture remains relatively intact.

8. Paiwan: scattered across both sides of the southern Central Mountain Range; about 86,000 people.

9. Rukai: around Maolin Township in Kaohsiung County, Wutai Township in Pingtung County, and Donghsing Township in Taitung County, about 11,600 people.

10. Tsou: primarily in Alishan Township in Chiayi County, Sinyi Township in Nantou County, and Tauyuan and Namasia townships, Kaohsiung County, about 6,500 people.

11. Bunun: scattered across the central mountainous areas between 1,000 and 2,000 $\mathrm{m}$ a.s.1., about 50,000 people.

12. Thao: primarily in Yuchih and Shueili townships in Nantou County, about 648 people.

13. Sediq: Chilai plain of Hualien County, about 10,000 people.

14. Saisiyat: primarily in Wufeng Village of Hsinchu County and in Nanjuang and Shitan villages of Miaoli County, about 5,300 people.

\section{Formosan languages}

Language trees place the arrival of original Austronesians in Taiwan at approximately 5,230 years ago and suggest a series of settlement pauses and expansion pulses linked to technological and social innovations (Gray et al. 2009). Thus, the study of aboriginal Taiwanese languages, known as Formosan languages, is significant. About a dozen Formosan languages currently exist and are quite divergent. The Formosan languages contain many interesting linguistic features not found in any other Austronesian languages outside of Taiwan. Diachronically, they contain many archaic features, so their study is crucial to reconstruct the Proto-Austronesian (PAN) language spoken about 5,000 to 6,000 years ago. However, adequate descriptions and data are available for only a few of these languages, such as Atayal, Seediq, Tsou, Rukai, Bunun, Amis, Paiwan, and Kavalan. Most of the other languages are still poorly understood (Li 2000). Of the approximately 26 known Formosan languages, at least ten are extinct, five are moribund (Zeitoun and Yu 2007), and several are endangered. These languages have unique historical significance, because most historical linguists consider Taiwan to be the original homeland of the Austronesian language family (Blust 1985).

\section{Archeological studies of early inhabitants of Taiwan}

The earliest inhabitants of Taiwan had pre-ceramic assemblages. These have been dated from 20,000-30,000 to 5,000 BP in the cave site at Chang-pin on the east coast of Taiwan and at the O-luan-pi II and Lung-keng sites on the south coast (Sung 1969; Li 1985). These assemblages have been defined as the "Chang-pin Culture" and are characterized by a lithic industry consisting of chipped pebble and flake tools, as well as the absence of pottery and no evidence of farming. However, we lack evidence to support a relationship between the Chang-pin Culture and the earliest Austronesian-speaking peoples.

Which Neolithic culture or cultures might represent the earliest PAN-speaking peoples? In the 1940s, Dr. Kano Tadao was the first to suggest that the earliest Neolithic cultural stratum in Taiwan was characterized by cordmarked pottery (Tadao 1955). The identification of characteristics and formal establishment of an archeological culture were not completed until Kwang-chih Chang's 19641965 excavations of the Ta-pen-keng site in Taipei and Feng-pi-tou site in Kaohsiung County. Chang (1969, 1989) named the culture "Ta-pen-keng (TPK)" and described it as having the following characteristics:

1. Pottery made of coarse paste and decorated with cordmarked impressions

2. The oldest Neolithic cultural horizon found to date in Taiwan, apparently antedating the subsequent prehistoric culture, which began round 2,500 $\mathrm{BC}$ 
3. A subsistence base of hunting, fishing, and collecting; some forms of farming, such as root and fruit cultivation

4. Settlements located on marine and river terraces, not far from water sources

5. Evolution in a humid and warm subtropical-tropical environment

During the last two decades, more TPK sites have been found around the southern, northern, and eastern coasts of Taiwan (Chen 2000; Liu 1995, 2000, 2002; Lien and Sung 1986; Tsang 2005, 2007, 2010; Tsang et al. 1994, 2004). The sites with the earliest data are Nan-kuan-li and Nan-kuan-li East in southern Taiwan. Ten ${ }^{14} \mathrm{C}$ dates obtained from these sites indicate that they were formed between 3,000 and $2,500 \mathrm{BC}$. The pottery unearthed from Nan-kuan-li is mainly jars and bowls, dark or reddish brown in color, with cordmarked, painted, and incised decorations. Stone tools were mainly polished adzes, arrowheads, and net sinkers. Instead of stone knives, a large number of reaping knives, made of windowpane oyster (Placuna placenta) shells, were recovered. A few bone and antler artifacts were uncovered, including points, chisels, and bead and pendant ornaments. Fourteen burials were recovered, most of which were in a supine and extended posture, with their heads all pointing toward the south. A large number of faunal and plant remains were recovered. Major faunal remains included bones of fish, deer, pigs, and dogs. Plant remains consisted mainly of rice (Oryza sativa), foxtail millet (Setaria italica), quassia wood (Picrasma quassioides), and Chinese hackberry (Celtis sinensis) seeds.

Here, we mainly report on work at the Nan-kuan-li and Nan-kuan-li East sites near the Science-Based Industrial Park in southern Taiwan. This is the drainage area of the Zengwun River. Many sites have been excavated, with dates obtained for at least every 500 years since $\sim 5,000$ BP. Tens of thousands of both rice and foxtail millet seeds were found at a single site, so cereals were important crops at the early stage of the PAN-speaking population about 5,000 years ago, as predicted by Gray et al. (2009).

Figure 2 illustrates the farming tools (shell knife and stone hoe) and carbonated seeds (rice and foxtail millet) excavated from the sites. The shell knife may have been used for harvesting rice panicles. Most of the excavated rice seeds were dehulled, with the glume, palea, and lemma removed. However, many of the foxtail millet seeds were hulled (i.e., consisting of the glume).

From these findings, we can modify some of the points of TPK culture addressed by Chang $(1969 ; 1989)$ :

1. TPK is the oldest Neolithic cultural horizon found to date in Taiwan, and it began around 3,000 BC.

2. The subsistence base was hunting, fishing, and farming. Cultivation of cereals mainly involved rice and foxtail millet; roots and fruit were also cultivated.

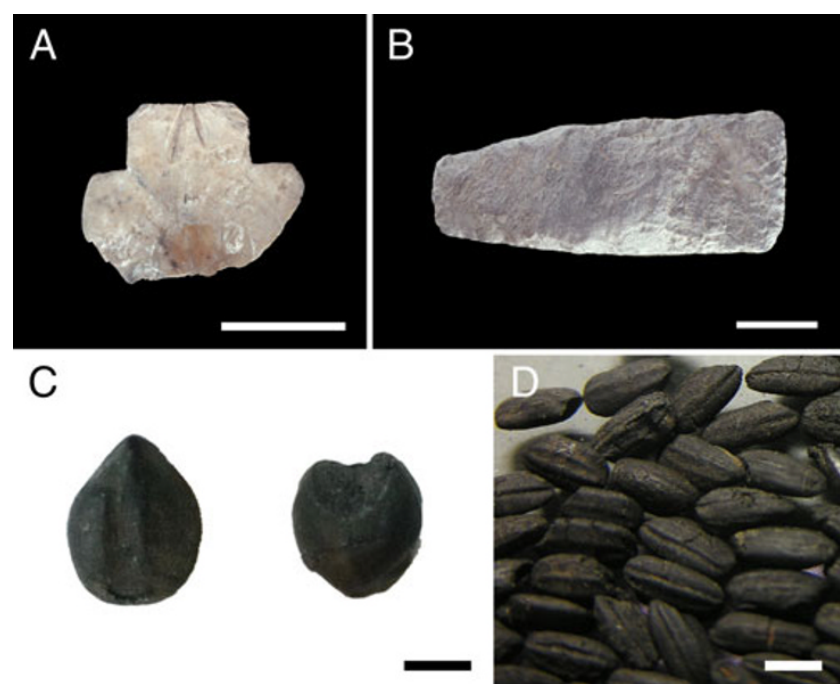

Fig. 2 Farming tools and carbonated seeds excavated from Nan-kuan-li and Nan-kuan-li East sites in southern Taiwan. a Shell knife $B a r=5 \mathrm{~cm} . \mathbf{b}$ Stone hoe. Bar $=5 \mathrm{~cm}$. c Intact (left) and dehulled (right) carbonated foxtail millet seeds. Bar $=1 \mathrm{~mm}$. d Carbonated rice seeds. Bar $=5 \mathrm{~mm}$.

\section{Rice landraces cultivated in aboriginal villages}

The beginnings and spread of rice agriculture are related to the cultural and linguistic developments of early Asian societies. Using archeological studies and sequence analysis of domestication-related genes, McCouch and colleagues recently provided new insights into the history of rice domestication (Kovach et al., 2007). The proposed origin and dispersal of domesticated rice is illustrated in Fig II of that paper, which denotes the possible paths of domesticated rice dispersal. One of the paths of dispersion coincided well with the migration pattern of the early Austronesians, which suggests a positive relation between the migration of Austronesian peoples and the dispersal of domesticated rice.

The major staple crops in Taiwan's aboriginal villages are rice and foxtail millet. About 100 years ago and during the Japanese colonial period, Dr. Iso, a famous rice breeder, collected about 60 rice landraces from the aboriginal villages in the high mountain areas of Taiwan. These seeds were well preserved then transferred to the Taiwan Agriculture Research Institute in 1945. However, the samples contained only landrace names and seeds, with no record of the location or village where they were collected. Several linguists helped identify the possible tribes where these landraces came from. Currently, we have good information for about ten landraces.

These 60 rice landraces show wide variation in phenotype, including grain size, plant size and architecture, aboveground biomass, heading habitat, and drought tolerance. Figure 3 illustrates the phenotype of several plant types and seed phenotypes. Many of them consist of awns and partial shattering; that is, they do not exhibit the features of modern varieties. 
Fig. 3 Examples of the 60 rice landraces collected from aboriginal Taiwanese villages about 100 years ago. a $1-9$ plant types. b Hulled and unhulled rice seeds.


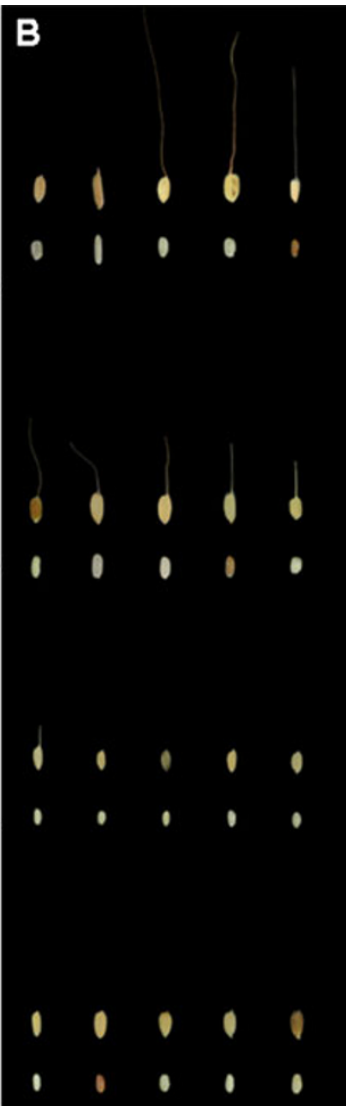

Studies of domestication-related rice genes

Domestication involves a series of profound genetic changes resulting from selections to make wild species easier for cultivation and better for consumption. For rice domestication, the major traits altered include the following:

1. Grain: size, shape, color, fragrance, amylose content

2. Seed: shattering behavior, awn, panicle size and shape

3. Plant structure: more tillers, not spread out

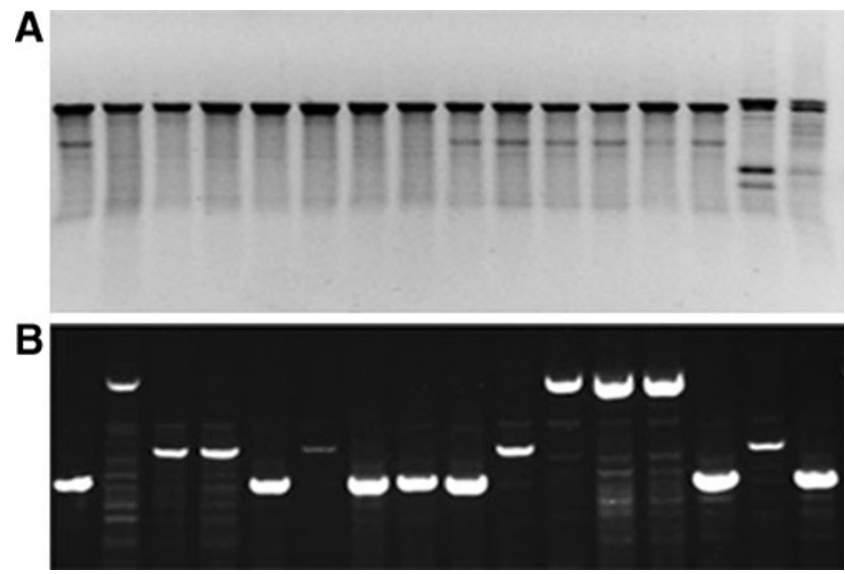

Fig. 4 Huge variations occurred at the domestication-related genes of the 60 rice landraces. a TILLING analysis of Ehdl gene using 16 landraces. b Gel analysis of $H d 1$ gene using 16 landraces. 


\section{Heading or flowering: photoperiod sensitive}

Using these 60 rice landraces, we worked on 16 domestication-related genes, including three grain shaperelated genes, one grain color gene, one seed dormancyrelated gene, one grain fragrance-related gene, three genes controlling grain shattering, and one gene controlling sticky rice features (Table 1). These genes have been widely used in other domestication-related rice research.

Rice is short-day plant and can be harvested only once when grown in high-latitude areas such as Japan, Korea, and Northern China. However, Taiwan's latitude is $22^{\circ}$ to $25^{\circ}$, so it is subtropical and thus allows for two annual rice harvests if plants are not sensitive to day length or temperature. We investigated several of the 60 rice landraces and found six genes-Ehd1, Ehd2, Hd1, Hd3a, Hd6, and Se5-that control flowering time, also known as heading date, which would benefit for two harvests.

We revealed the sequence variations of these domesticationrelated genes by analysis with Targeting Induced Local Lesions in Genomes (TILLING), then DNA sequencing. The sequence variations include many single-nucleotide polymorphisms; deletions and insertions, located at promoters, exons, or introns. TILLING results provided us with clues to choose landraces for detailed PCR and/or sequencing studies. Figure 4 illustrates part of the TILLING and gel analysis, indicating that huge differences are present in the landraces used.

\section{Conclusions and future prospects}

Further investigation is needed into the beginnings and spread of rice agriculture and its relation to language dispersal and social transformations in early Asia. Taiwan's aboriginal peoples and their agriculture are especially interesting in this regard because they are thought to be related to the original Austronesians. Findings from the earliest excavated sites in Taiwan are dated about 5,000 BP. We suggest that the people that inhabited these sites came from the north, from the Asian mainland, because large amounts of carbonated rice and foxtail millet (domesticated in the north) were found at archeological sites of early cultures. Through detailed analyses of the rice landraces from Taiwan and other Austronesian villages in Southeast Asia, we may understand the relationship between their haplotypes. In conjunction with archeologists and linguists, we should be able to understand the rice cultivation history of Taiwan and nearby areas.

Acknowledgments We greatly acknowledge the critical review of Ms. Laura Small and Krisa Fredrickson of this manuscript. This work was supported by grants from Academia Sinica (022316 to YI Hsing) and the National Science Council (NSC 95-2420-H-001-010 to KT Li, NSC992420-H-001-008 and NSC100-2420-H-001-014 to CH Tsang) of Taiwan.

\section{References}

Blust R. The Austronesian homeland: a linguistic perspective. Asian Perspectives. 1985;26(1):45-67.

Bradbury LM, Fitzgerald TL, Henry RJ, Jin Q, Waters DL. The gene for fragrance in rice. Plant Biotechnol J. 2005;3:363-70.

Bradbury LM, Gillies SA, Brushett DJ, Waters DL, Henry RJ. Inactivation of an aminoaldehyde dehydrogenase is responsible for fragrance in rice. Plant Mol Biol. 2008;68:439-49.

Chang KC. Fengpitou, Tapenkeng and the Prehistory of Taiwan. Yale University Publications in Anthropology No 73. New Haven: Yale University; 1969.

Chang KC. Taiwan archaeology in Pacific perspective. In: Chang KC, Yin CC, Li KC, editors. Anthropological studies of the Taiwan area: accomplishments and perspectives. Taipei: Department of Anthropology, National Taiwan University; 1989. p. 87-97.

Chen YP. Report on the test excavation of archaeological sites in the fourth nuclear power plant of Taiwan Power Company. [In Chinese.]. Taipei: Taiwan Power Company; 2000.

Fan C, Xing Y, Mao H, Lu T, Han B, Xu C, Li X, Zhang Q. GS3, a major QTL for grain length and weight and minor QTL for grain width and thickness in rice, encodes a putative transmembrane protein. Theor Appl Genet. 2006;112:1164-71.

Gray RD, Drummond AJ, Greenhill SJ. Language phylogenies reveal expansion pulses and pauses in Pacific settlement. Science. 2009;323:479-83.

Hill C, Soares P, Mormina M, et al. A mitochondrial stratigraphy for Island Southeast Asia. Am J Hum Genet. 2007;291:1735-7.

Izawa T, Oikawa T, Tokutomi S, Okuno K, Shimamoto K. Phytochromes confer the photoperiodic control of flowering in rice (a short-day plant). Plant J. 2000;22:391-9.

Ji H, Kim SR, Kim YH, Kim H, Eun MY, Jin ID, Cha YS, Yun DW, Ahn BO, Lee MC, Lee GS, Yoon UH, Lee JS, Lee YH, Suh SC, Jiang W, Yang JI, Jin P, McCouch SR, An G, Koh HJ. Inactivation of the CTD phosphatase-like gene OsCPL1 enhances the development of the abscission layer and seed shattering in rice. Plant J. 2010;61:96-106.

Kojima S, Takahashi Y, Kobayashi Y, Monna L, Sasaki T, Araki T, Yano M. Hd3a, a rice ortholog of the Arabidopsis FT gene, promotes transition to flowering downstream of $\mathrm{Hdl}$ under short-day conditions. Plant Cell Physiol. 2002;43:1096-105.

Konishi S, Izawa T, Lin SY, Ebana K, Fukuta Y, Sasaki T, Yano M. An SNP caused loss of seed shattering during rice domestication. Science. 2006;312:1382-96.

Kovach MJ, Sweeney MT, McCouch SR. New insights into the history of rice domestication. Trends Genet. 2007;23:578-87.

Li KC. Report of archeological investigations in the Kenting National Park on Southern tip of Taiwan. Pingtung: Kenting National Park Administration Office; 1985.

Li PJK. Formosan languages: the state of the art. In: Blundell D, editor. Austronesian Taiwan: linguistics, history, ethnology, and prehistory. Berkeley: Phoebe Hearst Museum of Anthropology; 2000. p. 45-67.

Li C, Zhou A, Sang T. Rice domestication by reducing shattering. Science. 2006;311:1936-9.

Lien, CM \& Sung WH. Analysis and research on the stratigraphy and artifacts unearthed from the cultural layers. In: Report on the analysis of the excavated materials from the Pei-nan site [in Chinese]. Taipei: Ministry of Education; 1986

Liu YC. Investigations on the resources of prehistoric cultures, history of humanity, visual environment in the Chi-san-yian Historical Park. [In Chinese.]. Taipei: Department of Civil Affairs, Taipei Municipal Government; 1995.

Liu YC. Investigations and studies of archaeological sites in Taipei City. [In Chinese.]. Taipei: Department of Civil Affairs, Taipei Municipal Government; 2000. 
Liu YC. Prehistoric cultures and population groups in the lower valley of the Tan-shui River, Taipei. [In Chinese.]. Taipei: The Shi-sanhang Museum of Archaeology; 2002.

Matsubara K, Yamanouchi U, Wang ZX, Minobe Y, Izaw T, Yano M. Ehd2, a rice ortholog of the maize INDETERMINATE1 gene, promotes flowering by up-regulating Ehdl. Plant Physiol. 2008;148:1425-35.

Saito H, Yuan Q, Okumoto Y, Doi K, Yoshimura A, Inoue H, Teraishi M, Tsukiyama T, Tanisaka T. Multiple alleles at early flowering 1 locus making variation in the basic vegetative growth period in rice (Oryza sativa L.). Theor Appl Genet. 2009;119:315-23.

Shomura A, Izawa T, Ebana K, Ebitani T, Kanegae H, Konishi S, Yano M. Deletion in a gene associated with grain size increased yields during rice domestication. Nat Genet. 2008;40:1023-8.

Song XJ, Huang W, Shi M, Zhu MZ, Lin HX. A QTL for rice grain width and weight encodes a previously unknown RING-type E3 ubiquitin ligase. Nat Genet. 2007;39:623-30.

Sugimoto K, Takeuchi Y, Ebana K, Miyao A, Hirochika H, Hara N, Ishiyama K, Kobayashi M, Ban Y, Hattori T, Yano M. Molecular cloning of $S d r 4$, a regulator involved in seed dormancy and domestication of rice. Proc Natl Acad Sci USA. 2010;107:5792-7.

Sung WH. Changpinian: a newly discovered preceramic culture from the agglomerate caves on the east coast of Taiwan: a preliminary report. Newsletter of Ethnological Society of the Republic of China. 1969;9:1-27.

Sweeney MT, Thomson MJ, Pfeil BE, McCouch S. Caught redhanded: $R c$ encodes a basic helix-loop-helix protein conditioning red pericarp in rice. Plant Cell. 2006;18:283-94.

Tadao K. Outlines of archaeological and ethnological studies of Taiwan. Translated by WH. Sung. Taipei: Wenxian Weiyuanhui; 1955.

Takahashi Y, Shomura A, Sasaki T, Yano M. Hd6, a rice quantitative trait locus involved in photoperiod sensitivity, encodes the alpha subunit of protein kinase CK2. Proc Natl Acad Sci USA. 2001;98:7922-7.
Tsang CH. Recent discoveries at the Tapenkeng culture sites in Taiwan: implications for the problem of Austronesian origins. In: Sasgart L, Blench R, Sanchez-Mazas A, editors. The peopling of East Asia. London: Routledge Curzon; 2005. p. 63-74.

Tsang CH. Neolithic interaction across the Taiwan Strait-implications for the issue of Austronesian origin and dispersal. In: Gadu MZ, Lin HM, editors. 2009 International Symposium on Austronesian Studies. National Museum of Prehistory: Taitung; 2010. p. 1-11.

Tsang CH, Chen CY, Liu YC. General survey of archaeological sites in Kao-hsiung County and Kao-hsiung City. Taipei: Ministry of Interior Affairs; 1994.

Tsang CH, Li KT, Chu CY. The term report of the archaeological project for rescuing the unpreserved area of the Daoyie Site in Taiwan Science-Based Industrial Park. Taipei: Institute of History and Philology, Academia Sinica; 2004.

Tsang, CH. Recent archaeological discoveries in Taiwan and Northern Luzon: implications for the Austronesian dispersal. In: From Southeast Asia to the Pacific: archaeological perspectives on the Austronesian expansion and the Lapita Cultural Complex. Taipei: Research Center for Humanities and Social Sciences, Academia Sinica; 2007. P. 63-91.

Yamanaka S, Nakamura I, Watanabe KN, Sato Y. Identification of SNPs in the waxy gene among glutinous rice cultivars and their evolutionary significance during the domestication process of rice. Theor Appl Genet. 2004;108:1200-4.

Yano M, Katayose Y, Ashikari M, Yamanouchi U, Monna L, Fuse T, Baba T, Yamamoto K, Umehara Y, Nagamura Y, Sasaki T. Hdl, a major photoperiod sensitivity quantitative trait locus in rice, is closely related to the Arabidopsis flowering time gene $C O N$ STANS. Plant Cell. 2000;12:2473-84.

Zeitoun E. The Formosan language archive. The indigenous conference on aboriginal languages: theory and practice. Taipei. 2007. p. $28-42$. 